\title{
岐阜大学工学部 化学・生命工学科 生命化学コース 竹森研究室
}

濱本 明恵 (岐阜大学工学部)

E-mail: ahama@gifu-u.ac.jp

\section{1. 岐阜大学について}

岐阜県は「清流の国」と称されるように、美しい川や 豊かな自然に恵まれ、飛騨牛や鮎をはじめとした自然を 生かした食材も豊富な風光明媚なところです。また、織 田信長や関ケ原といった歴史上有名な人物や舞台も多く 存在し、鵜飼などの伝統的な文化や美濃焼や美濃和紙を はじめとした工芸品、白川郷などの世界遺産も存在する 地味ながらも魅力のある土地です。岐阜大学はそんな岐 阜県の中核部である岐阜市に存在します。5つの学部(教 育学部、地域科学部、医学部、工学部、応用生物科学部) とほぼ全ての施設が 1 か所に集約されたキャンパスで す。岐阜駅から大学まではバスで 30 分かかり、大学周 辺は田畑の多いところですが、大型のスーパーや飲食店 が複数あるので生活は便利です。また、岐阜駅から名古 屋駅まではJR の快速で 20 分とアクセスもよく、娛楽 などにも不自由はしません。大学内には川が流れており、 水鳥の姿をよく見かけたり、様々な樹木や植物が生息し て四季折々の花を咲かせたりと、季節の変化が良く感じ られる自然豊かなキャンパスです。

\section{2. 研究室について}

岐皁大学工学部には社会基盤工学科、機械工学科、電 気電子・情報工学科、化学・生命工学科が存在しており、 私たちが所属するのは化学・生命工学科の生命化学コー スです。基礎研究だけでなく、より実用化・商品化を意 識した研究や、技術者の育成を重視した教育が行われて います。また、岐阜大学は地域志向型であり、地元企業 と連携して様々な開発を行うなど地方創生の一翼を担う 側面も有しています。

私達の研究室は 2017 年 1 月に竹森洋教授が着任さ れたことで発足し、現在 2 年目の新しい研究室です。 2018 年 2 月から、自身も助教として加わりました。竹 森研の現在 $(2018$ 年 11 月) のメンバーは教員 2 人、大 学院生 4 人、学部生 5 人の計 11 人です。研究室発足当 初はゼロからのスタートで大変でしたが、現在は研究環 境やメンバーの経験・技術も少しずつ充実してきており、 それぞれのペースで着実に日々の研究に励んでいます。 また、週一回は研究室内で英語論文の紹介または研究の 進捗報告を行っており、お互いの情報を共有し、ディス カッションする場としています。メンバー同士の関係も 良好で、同級生間だけなく先輩後輩で協力して研究を進 めたり、歓迎会や打ち上げなどのイベントも開催してい ます。

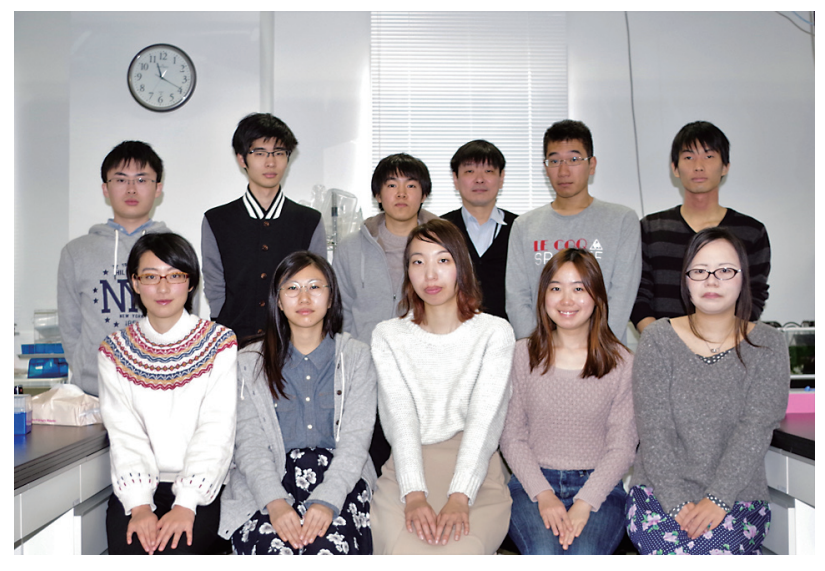

竹森研のメンバー

前列右端が濱本、後列右から 3 番目が竹森教授です。

\section{3. 研究内容について}

竹森研究室では、体色制御または疾患に焦点を当てた 研究を広く行っています。実験にはマウス、ゼブラフィッ シュ、ヒトの培養細胞や好中球、マウスの皮膚メラノー マ細胞などを利用しています。現在進行中の研究テーマ の一つは、「植物の抽出物や化合物ライブラリーを利用 したメラニン合成を制御する物質の探索とそのメカニズ ムの解析」です。中でも、ヌマダイコンやアマクサシダ と呼ばれる植物の抽出物と、ライブラリー中の化合物が、 それぞれメラニン合成を抑制し、ヒト皮膚メラノーマ細 胞などで美白効果を示寸事をこれまでに発見しました。 現在は、各抽出物および化合物がどのように細胞内メ力 ニズムや遺伝子発現を制御し、メラニン合成を抑制する のかについて解析を行っているところです。また、ヌマ ダイコン抽出物はメラニン合成の抑制のみならず、抗炎 症効果や血糖值・血中コレステロールの低下作用も示し たことから、その詳細なメカニズムの解明にも取り組ん でいます。本研究は、企業や地元農家と協力してヌマダ イコンの量産や機能性食品の開発も視野に入れているも のです。

また、ゼブラフィッシュを用いて、前述した美白効果 を示した植物抽出物や化合物が、哺乳類と同様のメカニ ズムでメラニン合成抑制作用を示すのかを解析していま す。他にもゼブラフィッシュを利用して、白斑評価の簡 便なモデル系の構築を目指しています。白斑とは皮膚が まだらのように見える疾患です。白斑の研究は主に皮膚 の培養細胞やマウスを用いて行われていますが、私たち はゼブラフィッシュにおいても白斑誘因物質を添加する ことで白斑様の症状を示すことを見出し、今後、白斑誘 発物質、抑制物質のスクリーニングにも活用したいと考 
えています。

その他にも、毛色変化やエネルギー代謝異常を示した 塩誘導性キナーゼ KO マウスの機能解析や、毛色が薄 い突然変異マウス (Hermansky-Pudlak syndrome 5 の遺 伝子欠損マウス) を用いた炎症性腸疾患の研究等も行っ ています。
着任間もないため自身の成果は限られていますが、今 後、研究を進展させ、比較内分泌学会等で皆様とディス カッションさせて頂く日を楽しみに、ますます研究活動 を頑張りたいと考えております。最後になりましたが、 今回このような執筆の機会を与えて頂いた編集委員の先 生方に厚く御礼申し上げます。 